Penal Policy and Social Justice 
Also by Barbara A. Hudson and published by Macmillan Justice through Punishment 


\title{
Penal Policy and Social Justice
}

\author{
Barbara A. Hudson
}


(C) Barbara A. Hudson 1993

All rights reserved. No reproduction, copy or transmission of this publication may be made without written permission.

No paragraph of this publication may be reproduced, copied or transmitted save with written permission or in accordance with the provisions of the Copyright, Designs and Patents Act 1988, or under the terms of any licence permitting limited copying issued by the Copyright Licensing Agency, 90 Tottenham Court Road, London W1P 9HE.

Any person who does any unauthorised act in relation to this publication may be liable to criminal prosecution and civil claims for damages.

First published 1993 by

THE MACMILLAN PRESS LTD

Houndmills, Basingstoke, Hampshire RG21 2XS

and London

Companies and representatives

throughout the world

ISBN 978-0-333-49576-6

ISBN 978-1-349-23071-6 (eBook)

DOI 10.1007/978-1-349-23071-6

A catalogue record for this book is available from the British Library. 
For Harry and Adam 


\section{Contents}

Preface ix

Introduction 1

1 Developments in Penal Policy during the 1980s 17

2 Penal Policy and Social Structure 55

3 Penal Policy and Social Policy $\quad 89$

4 Penal Policy and Criminal Justice 122

5 Some Ideas Whose Time Has Come 149

6 Punishment, Justice and the Problem of Law 178

$\begin{array}{ll}\text { Bibliography } & 201\end{array}$

$\begin{array}{ll}\text { Index } & 219\end{array}$ 


\section{Preface}

This book started life as a research project with Middlesex Area Probation Service, and I am grateful to the management and staff there for encouragement to undertake the original sentencing survey, and for agreement that the questions it seemed to generate were interesting to people other than myself, as well as for practical help with data collection. The latter stages of the book's development have been enriched by a new partnership with Northumbria Probation Service, and again I am grateful to colleagues at all levels of the service for sharing with me some of their hopes and their concerns about the way penal policy is affecting criminal justice practice.

A grant from the Leverhulme Trust enabled me to have some time between leaving Middlesex and commencing my duties with the University of Northumbria, and this was crucial in allowing me some space to further analyse the original data and develop the theoretical ideas which enabled me to see what was happening in the Middlesex courts as part of a much more general trend. In turning a collection of data into a book with wider themes, I have been much assisted by comments by Maureen Cain and Carol Smart on my first proposals, and by the patience and timely advice of Steven Kennedy and Frances Arnold at Macmillan. For help with bringing it some way down to earth again, I am indebted to the anonymous reviewer used by the publisher. In providing evidence to support my central contention that whatever the differences in penal policy with respect to crimes, the same groups of people are penalised everywhere, I am grateful to Dick Whitfield for his list of contacts, and to Inkeri Antilla, David Biles, Else Holm, Jacqueline de Plaen and Knut Sveri for the helpful material they so generously sent to me.

For encouraging me to believe that I had something worth saying and had better get on and say it, thanks to Andrew Ashworth, Dee Cook, Tony Jefferson, Roger Matthews and, especially, Pat Carlen. Between carrying out the original research which prompted the book and finally getting down to writing it, I have moved from being a researcher, employed by the probation service, back into teaching. Colleagues at Newcastle have been supportive, students have been challenging; Heather Scott and Mat Curran in particular have managed not to look too bored when hearing for the umpteenth time about problems with this or that chapter, and their convivial friendship has been sustaining throughout. 
This book has had an embarrassingly long gestation period. Changing jobs, moving from one end of the country to another, as well as the often bewildering speed of developments in the penal policy field, made it difficult to settle down to the task of writing. New people to get to know, new courses to write, the beauty of the Northumbrian countryside and the acquisition of a large garden have all proved unchallengeable excuses or irresistible temptations not to work on the book, but I can only hope that the final result is the better for having a longer than envisaged time for reflection between the original idea and its realisation.

Above all, and as ever, I am grateful to Adam and Harry for love and patience. They have both assisted in countless ways: thanks Adam for doing the ironing and helping with tedious chores like checking references; thanks Harry for always listening (or at least convincingly pretending to) and for keeping the sherry flowing.

Barbara A. Hudson 